\title{
The 100th anniversary of the National Academy of Internal Affairs
}

\author{
Written by: \\ Volodymyr Vasylovych Cherniei \\ https://orcid.org/0000-0002-0247-263X \\ Doctor of Law, Professor, Rector of the National Academy of Internal Affairs, Ukraine. \\ Oleksii Yuriiovych Drozd \\ https://orcid.org/0000-0002-4514-6594 \\ Doctor of Law, Associate Professor, Acting Head of the Department of Doctorate and Post-graduate \\ Studies of the National Academy of Internal Affairs, Ukraine.
}

2021 marks the $100^{\text {th }}$ anniversary of the founding of the National Academy of Internal Affairs.

The history of its establishment begins with the creation of the Courses for the militiamen of the Kharkiv provincial militia on June 11, 1921 (from October 02, 1922 - the School of the Senior Commanding Staff of Workers' and Peasants' Militia of the USSR). On December 25,1922 at a meeting of the Council of People's Commissars of the USSR, it was decided to reorganize Kharkiv Militia School into the AllUkrainian School and to transfer it into State custody. Based on this decision, in 1923 the People's Commissariat of Internal Affairs took the necessary organizational steps, and according to the Order of the Militia and Criminal Investigation Service of the USSR of October 23, 1923, 121 educational institutions were renamed the All-Ukrainian School of Militia and Criminal Investigation. Thus, the school acquired the status of Republican. The All-Ukrainian school began to train senior command staff for the militia throughout Ukraine.

In 1925 the All-Ukrainian school was relocated from Kharkiv to Kyiv. The school was renamed the School of Senior Commanding Staff of Workers' and Peasants' Militia in 1936.

At the end of the World War II, the All-Ukrainian School of the NKVD of the Ukrainian SSR began to function in Kyiv. Subsequently, the reorganization of the Ministry of Internal Affairs - NSA caused the change in the subordination of the school, as well as its renaming to: AllUkrainian School of the NKVD (1944), Kiev School of the NKVD (1946), Kiev Officer School of the Ministry of Internal Affairs (1948), Kiev School of the Ministry of Internal Affairs (1950).

Kyiv Special Secondary School of Militia of the Ministry of Internal Affairs of the USSR was organized by the Order of the Ministry of Internal Affairs of the USSR of August 20, 1956 and began training specialists for basic police services with a two-year training course (three years in correspondence).

In 1957, a correspondence department of the USSR Ministry of Internal Affairs and in 1958 Kyiv branch of the USSR Ministry of Internal Affairs was established.

On April 11, 1960, a government decree was passed to establish the Higher School of the Ministry of Internal Affairs of the Ukrainian SSR by merging the branch of the Higher School of the Ministry of Internal Affairs of the USSR and Kyiv Special Militia Secondary School, the last course of which became the Higher School.

In 1968, the school became known as Kyiv Higher School of the USSR Ministry of Internal Affairs.

After the proclamation of the independence of Ukraine, in accordance with the Resolution of the Cabinet of Ministers of Ukraine of January 27, 1992, the Ukrainian Academy of Internal Affairs was established on the basis of the USSR Ministry of Internal Affairs and Kyiv branch of the All-Union Institute for Advanced Training of Directors of Correctional Institutions.

It was granted the status of the National in December 1996 by the Decree of the President of Ukraine and became known as the National Academy of Internal Affairs of Ukraine. In 1997 the Academy received the highest, $4^{\text {th }}$ level of accreditation.

In September 2005, National Academy of Internal Affairs of Ukraine was reorganized and renamed Kyiv National University of Internal Affairs. 


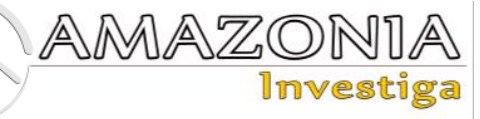

According to the order of the Cabinet of Ministers of Ukraine "On re-organization of some educational institutions of the Ministry of Internal Affairs" of August 27, 2010, the university was reorganized into the National Academy of Internal Affairs (hereinafter - the Academy). The status of the National Academy was confirmed by the Decree of the President of Ukraine "On the National Academy of Internal Affairs" of August 31, 2010.

In 2014, Volodymyr Vasylovych Cherniei, Doctor of Law, Professor, and General of Police of the Second Rank, was appointed Rector of the Academy.

The Academy as an educational, scientific and practical complex provides educational services for training for Bachelor's and Master's degrees in the areas of "Law", "Law Enforcement", "Public Administration" and "Psychology" for the criminal police units, operational service units, counteraction cybercrime units, criminal analysis units, preventive activities units, investigators, detectives, forensic experts, polygraph examiners and instructors in emergency medical assistance (about 13 000). This is the Academy where the formation of the new generation of police officers has begun; retraining and advanced training of all major categories of basic police specializations, including KORD, and civil servants of central executive bodies is carrying out (up to 3000 annually).

The personnel of the Academy is a reserve of the Ministry of Internal Affairs and a reliable partner of the capital and other police garrisons in the protection of public order and security during mass events and in case of emergencies. Graduates and employees are directly involved in ensuring the sovereignty and territorial integrity of the State in the Eastern Ukraine, sometimes, unfortunately, at the cost of their own lives and health.

The Academy has trained 112000 law enforcement officers during the years of independence, who hold various positions in the Central Office of the Ministry of Internal Affairs, territorial divisions of the National Police of Ukraine, the Expert Service of the Ministry of Internal Affairs, as well as in prosecution services, justice, the Security Service of Ukraine, the State Tax Service, the State Customs Service, the State Penitentiary Service, the judiciary, in the legal area, etc. There are more than 250 generals and Heroes of Ukraine among the graduates and employees of the Academy of different years.

There are five specialized scientific councils in the Academy for the defense of dissertations for higher degrees of Doctor of Science and Doctor of Philosophy in eight scientific specialties, successfully developing new scientific schools on researches of fundamental and applied nature, a number of which are marked by State prizes and patents on inventions.

The Academy is known for its high scientific potential: the educational process and scientific work are provided by five educational and scientific institutes and faculty, 24 departments, 4specialized scientific laboratories with 55 Doctors and Professors, 372 Candidates of Sciences, 225 Associate Professors and Senior Researchers (among them - 11 Academicians and Corresponding Members of branch academies of sciences of Ukraine, 52 have honorary public titles).

Outstanding are the achievements of the institution in social and cultural life. In particular, educators take part in national and international competitions. Cadets and students are annual winners and graduates of prestigious international and national competitions, contests, exhibitions; they receive awards and scholarships of the President of Ukraine, Government, National Academy of Sciences of Ukraine, Kyiv Mayor. They also provide free legal aid to the population by taking part in the work of legal clinics.

The Legal Lyceum Yaroslav Kondratiev of the National Academy of Internal Affairs in the context of social protection enrolls children, whose parents were law enforcement officers, who lost their lives or were injured in the line of duty, including during the Joint Forces operation (anti-terrorist operation).

The institution has significantly strengthened and expanded the educational, scientific and logistical base and infrastructure. New modern buildings and special purpose facilities have recently been put into operation.

The international prestige of the academy is shown up in its membership in the Association of European Police Colleges, the Conference of Heads of Higher Police Institutions of Central and Eastern Europe, active cooperation with international organizations (Council of Europe, European Union Advisory Mission, UN Office in Ukraine, NATO Office in Ukraine, International 
Police Association, a number of foundations, etc.), educational institutions and police stations of different countries. The Academy is the only certified institution in Ukraine for training the personnel of the Ministry of Internal Affairs of Ukraine, the National Police of Ukraine and the National Guard of Ukraine for UN, EU and OSCE peacekeeping missions.
According to the annual independent sociological research, National Academy of Internal Affairs is recognized as one of the best institutions of higher education in law enforcement. 